\title{
BRICS e o rumo de uma liderança inexistente
}

\author{
Jaqueline Ganzert Afonso ${ }^{1}$
}

\section{RESUMO}

Os BRICS surgem como bloco sem uma identidade política. As características econômicas do acrônimo criaram uma expectativa de liderança que não ocorreu. $O$ desapontamento fora justamente o motor de críticas, que ora deveria ser ignorado, uma vez que o grupo foi criado sem o voluntarismo e a identidade assumida após sua constituição.

Palavras-chave: BRICS; Políticas públicas; Economia política.

As Cúpulas dos BRICS passaram a acontecer depois da identificação de possíveis lideranças no futuro da economia mundial. Países com grandes semelhanças econômicas seriam os responsáveis por gerir o futuro da comunidade internacional que não reconhecia mais o modelo apontado pelo velho sistema. Os BRICS foram assim denominados por possuírem em comum o perfil de desenvolvimento socioeconômico.

A característica principal deste grupo se deu principalmente pelo futuro de suas economias. As políticas públicas exercem forte influência no percurso de suas atividades. Em outras palavras, o intervencionismo estatal conduz a economia, a exemplo do campo energético, o qual os BRICS compartilham a estatização, além do setor monetário, compartilham o controle de mercado. Quando Jimmy O’Neil ${ }^{2}$ formulou o acrônimo BRIC ${ }^{3}$ buscava-se identificar as lideranças dentro do grupo dos países emergentes até 2050. Baseado no desenvolvimento econômico de mercado e consumo, O’Neil identificou um padrão entre a política, o PIB e a macroeconomia entre esses quatro países (O’NEIL, 2001).

\footnotetext{
${ }^{1}$ Mestre em Ciências Políticas pela Université de Montréal.

${ }^{2}$ Economista-chefe do banco de investimentos Goldman Sachs.

${ }^{3}$ A princípio o acrônimo era apenas BRIC. A África do Sul foi incluída apenas em 2011, passando a ser BRICS.
} 
Em paralelo às características apontadas por O’Neil, percebem-se, nestes países, características de políticas pública que tendem à intervenções públicas no mercado, além de um controle de diversos setores nas mãos de estatais. Enquanto as estatais passam a ser braços do governo, ou agências na definição de (WOO-CUMMINGS, 1999), essas empresas passam a controlar o seu setor. 0 controle de uma estatal significa, então, o controle do Estado.

Ao contrário de economias como a dos os Estados Unidos, Inglaterra e Canadá que trabalham em novos mercados como o de tecnologia, a economia dos BRICS ainda é fortemente relacionada à economia de matrizes energéticas. 0 controle deste setor indica que há um controle da produção industrial visto que a energia é componente da indústria. Logo, esta relação econômica permite afirmar que as políticas econômicas ainda são influenciadas por energias fósseis e a industrialização nos países do BRICS.

A principal e mais intensa diferença interna entre estes países são as características individuais na questão de estratégia na política internacional. Os BRICS agem individualmente, e não como grupo. Suas estratégias na política externa não condizem com o grupo, e buscam interesses individuais. Diferentemente da economia e desenvolvimento social que são compartilhados pelo conjunto, cada país possui um perfil e um objetivo na comunidade internacional que o encaminha para a questão da liderança de modos completamente diferente, algo que será aqui tratado mais adiante (HURREL, 2009).

O jeu de rôle dos BRICS foi testado logo em 2008. Em meio à crise internacional, os grupos foram analisados no papel de líder potencial. A chamada Grande Recessão 4 foi responsável pelo desencadeamento de reflexos institucionais. A crise criou um efeito dominó nas instituições financeiras americanas. A Grande Recessão tem seu histórico em 2001 quando a "bolha da internet" estourou.

A bolha da internet foi um fenômeno em que empresas abriram o mercado na internet e causaram uma supervalorização de suas cotas na bolsa de valores NASDAQ. Houve, então, um aumento de investimentos em um mercado especulativo, que ampliou a curva de valorização destas empresas na NASDAQ. Imediatamente, o mesmo índice

\footnotetext{
${ }^{4}$ A Grande Recessão trata-se da crise econômica que iniciou em 2008 e deu sinais de possível fim em 2012.
} 
que subira a 5000 pontos, despencou a 2000, sofrendo uma desvalorização de $150 \%$, em questão de dias. Tal fenômeno ficou conhecido como estouro da bolha da internet. 0 estouro causou impacto nas empresas que estavam dentro desta bolha em razão da internet, gerando reestruturações, falências e fusões (KRUGMAN, 2012).

Em meio à recessão internacional, os BRICS indicaram que suas políticas econômicas não estariam alinhadas. A realidade foi que os BRICS não possuíam sequer uma determinação de liderança. O grupo havia alcançado os resultados de desenvolvimento agindo sozinho ou em grupos regionais, com diferentes membros. A expectativa era que esse grupo surgisse como liderança naquele cenário instável. Contudo, curiosamente ou não, os BRICS mantiveram seus crescimentos individuais, sem oferecer estrutura organizada de liderança na situação de crise.

Individualmente, cada um dos membros dos BRICS possui perspectivas diferentes na política internacional, o que serviria como justificativa para a ausência de componente de liderança:

- Enquanto o Brasil busca espaço na comunidade internacional como membro do Conselho de Segurança (CS), o mesmo possui uma política pacífica, diplomática e pouco persuasiva.

- $\quad$ A Rússia, por sua vez, ainda representa um contraponto das políticas dos Estados Unidos. Além disso, detém o poder sobre as fontes de energia da região, que fria e dependente de aquecimento, tem no gigante, além dos Montes Urais, o responsável pela energia região.

- A Índia é, talvez, o país do grupo com maiores probabilidades de utilizar seu poderio nuclear. Detentora de tecnologia e grande exportadora de cérebros, a Índia anseia maior interatividade na comunidade internacional.

- Por sua vez, a China membro do CS, entre as maiores economias superavitárias do mundo na atualidade, é a grande dúvida do grupo. Governada pelo Partido Comunista, grande parte de seus dados macroeconômicos oficiais são gerados por agências públicas e pouco se sabe sobre a veracidade dos dados. Do que se tem certeza são as condições geradas pelas relações comerciais com outros países. $\mathrm{Na}$ comunidade internacional é, junto com a Rússia, a estrategista pelo poder do veto. 
- $\quad$ Por fim, a África do Sul, recém-empossada no grupo, possui pouco poder na comunidade internacional. Surge como a representante africana, como representante da região.

Os perfis diferenciados das estratégias na política internacional conferem aos BRICS um caráter, ao menos atual, longe de ser líder. 0 que, com as atuais reuniões de cúpula e as frequentes propostas, pode em um momento incitar liderança. As reuniões começaram em 2009, justamente após o início da recessão, e anos após a proposta de O’Neil. A interpretação que se tem em relação às cúpulas é, principalmente, a de que estas se iniciaram após as críticas de falta de liderança do grupo.

Dessa forma, os resultados dos BRICS como líderes são falhos em comparação com a expectativa gerada em torno desse grupo quanto à condição de crise econômica no cenário internacional. Na realidade, os resultados dos BRICS foram aqueles esperados, se analisarmos o perfil individual de cada membro do grupo. É preciso relembrar que os BRICS não foram voluntariamente formados, mas indicados por seus índices de crescimento socioeconômicos, relativamente consistentes e coerentes. Isso significa que não houve iniciativas individuais, mas, por sugestão de analistas. Os resultados esperados de um grupo que foi montado não surpreende. Os fóruns e cúpulas mundiais em que os BRICS se reuniram foram resultantes da popularidade das comparações econômicas do grupo. Assim, a vontade dos BRICS de serem líderes em uma economia internacional não é refletida pelo posicionamento internacional desses países, mas sim, pelo desejo de analistas de se ter uma instituição no controle de uma economia em crise.

\section{Referências Bibliográficas}

BENAKOUCHE, Rabah. Economia da hegemonia do dólar. Textos de Economia, Florianópolis, v.12, n.2, p.80-97, jul./dez.2009

HURREL, Andrew et alli. Os Brics e a ordem global. Rio de Janeiro; Editora FGV, 2009. 
KRUGMAN, Paul. A crise de 2008 e a economia da depressão. Rio de Janeiro, Campus, 2009.

KRUGMAN, Paul. End this depression now!. New York. W. W. Norton \& Company, 2012.

O'NEILL, Jim. Building Better Global Economic BRICs. Global Economics Paper No. 66. Goldman Sachs \& Co.. 30 November 2001.

SCHNEIDER, Ben Ross. 1999. «The Desarollista State in Brazil et Mexico.» Dans dir. The Developmental State. Ithaca, NY: Cornell University Press.

SHEEHAN, Michael. The balance of power: history and theory. Routledgle, New York, 2000

WO0-CUMINGS, Meredith. 1999. «Introduction: Chalmers Johnson et the Politics of Nationalism et Development.» IN: The Developmental State. Ithaca, NY: Cornell University Press. 